\title{
PIT Community Extension Programs: The Three -Year Engagement
}

\author{
Ma. Marilyn L. Olavides ${ }^{1}$ Antonia D. Mendoza ${ }^{2}$ Jenney P. Bacalla ${ }^{3}$ \\ Faculty, College of Graduate Studies Palompon Institute of Technology Palompon, \\ Leyte 6538 Philippines
}

\begin{abstract}
The academe is one of the main actors in the society that could possibly effect change by way of extending services that are socially responsive to the needs of the community and its people. However, certain concerns have to be addressed to ensure sustainability and relevance of the services extended. As such, a study was conducted to look into the community extension programs of the Palompon Institute of Technology (PIT), rendered to its adopted barangay. The study used the mixed-method descriptive-evaluative design utilizing structured questionnaires, focus group discussions and interview schedule in obtaining relevant data. Results showed that while barangay residents/beneficiaries have learned skills from the livelihood trainings/activities conducted however, these have not fully benefited them due to lack of capital and opportunities. Overall results showed that the PIT's community extension programs and projects were successfully conducted. However the school needs to do something for the community to fully benefit the programs and projects. Linkages and partnerships with other agencies are suggested to attain project sustainability and more desirable outcomes.
\end{abstract}

Keywords- Impacts, Community Extension Services, Palompon

\section{INTRODUCTION}

Extension service is one of the three main functions of higher education or State Universities and Colleges (SUCs) in the country. It is the act of communicating and transferring knowledge and technology to specific sectors and target clienteles that will help them effectively improve production, uplift quality of life, and enhance the Higher Education Institution's academic and research programs [3]. Extension, according to Alcala [1], is a practical application of research outputs that are disseminated to the target beneficiaries to improve the lives of the people by increasing their incomes, thereby, reducing poverty.

Republic Act 8292 otherwise known as the "Higher Education Modernization Act of 1997" mandates institutions of higher learning like State Universities and Colleges (SUCs) in the Philippines to establish research and extension where such will promote the development of the latter [14]. That is, the SUCs are mandated by law to serve the depressed communities, the poorest of the poor, the less privileged, the deprived and the oppressed people [2]. Consistent with this, CHEd Chairperson Patricia Licuanan, in her message during the recognition of the 2010 Outstanding HEI Extension Programs [9], emphasized the importance of the conduct of extension work that is relevant and responsive to the needs of the community.

In response to the preceding mandate, HEIs/SUCS in the Philippines recognize their vital role and social responsibility in the society which is to translate the institution's involvement in community development. They establish institutional extension centers/offices and design extension programs that are relevant and responsive to the needs of the community. HEIs extend services to the deprived and less privileged people or those living in the depressed areas by providing extension services, such as programs, projects, and activities, researchbased knowledge or technology that are in line with the school's curricular programs offered.

The Palompon Institute of Technology (PIT), like other institutions of higher learning, has also established its own Extension Service Center/Office. The office which is in charge of initiating, catalyzing and sustaining the development of various communities in the service area of PIT using the school's expertise, research outputs and available resources [11]. The office actively exercises its role and functions by way of extending services to the people of its identified adopted barangays. PIT's community extension programs be analogous to what Bidad and Campiseño said concerning the extension programs of the majority SUCs in the state, which according to them, both demand-driven extension programs are community-based that encompass basic functional needs and demands of the community designed to establish and promote their general well- 
being. Accreditation-driven, on the other hand, are extension programs implemented to respond to the requirements of an accrediting body [2].

PIT then implements the "demand-driven" and "accreditation-driven" extension programs rendered to its adopted barangays, the latest of which is Barangay Canipaan - one of the identified depressed barangays in Palompon, Leyte [5]. On the other hand, a Memorandum of Understanding (MOU) was entered into by and between PIT and Barangay Canipaan which signaled the school to kick-off and conduct the training needs and resources assessment of the community which became the basis of its community programs and projects for the community. As such, to help improve the delivery of the services rendered to the community, this study was conducted.

\section{Objectives of the Study}

The main purpose of this study was to investigate the impacts of the community extension programs of the Palompon Institute of Technology (PIT) rendered to its adopted barangay - the Barangay Canipaan.

Specifically, the study was conducted to:

1. look into the extent of participation of the barangay residents in the PIT's extension programs/projects/activities;

2. investigate the effect of the extension programs/projects/activities on the barangay residents and the community;

3. understand how the residents feel about the extension programs/projects/activities and their impact on their lives and the community.

\section{Methodology}

The quantitative-qualitative approach was used in the study, utilizing the descriptive-evaluative mixed method of research. A combination of these methods was employed in the study considering that both quantitative and qualitative data were collected and analyzed together to answer the questions at hand, which later on would be used to evaluate and describe the studied phenomenon. The study was conducted at Barangay Canipaan of Palompon, Leyte, Philippines. It has 1,215 population representing 2.09\% of the total population of Palompon (2015CensusRecord). The village is 18 kilometers from the town with four Sitios, namely, Mahayahay, Mat-i, Crossing, and the barangay proper. The participants of the study were the barangay residents who included the fathers, mothers, out of school youths, high school students, and some illiterates who voluntarily participated in the community extension activities.

The questionnaire used was patterned from the research tool used by Dugyon [6], Herrera [8] and Dilao [4]. Slight revisions of some statements were made to fit them into the present study. It underwent improvement and validation by submitting them to identified faculty and other experts in the locality. Comments and suggestions were the bases in improving the items to come up with the final form. The final form was then translated into Cebuano (mother tongue) for the participants to have full understanding of the questions and statements.

\section{Data Collection}

The study used the triangulation technique of data gathering, utilizing survey questionnaires, interview schedules, and focus group discussions (FGDs). The quantitative data were gathered using the survey questionnaires while the qualitative data were gathered using FGDs and interview guides.

For the quantitative data collection, the researchers personally fielded the questionnaires with the help of the assigned facilitators and enumerators in the four sitios of Barangay Canipaan. After which, data were tabulated and analyzed using descriptive statistics such as simple percentage, frequency count, and weighted mean. For the qualitative data, the researchers personally went to the field and conducted focus group discussions and semi-structured interviews with the barangay residents. During the FGDs, each participant was given 5 to 10 minutes to answer few questions about the school's community extension activities. This was followed by participants' sharing of answers and group discussions were facilitated by the researchers. Note takings and recording were done during the activity which was limited to one hour per group. The collected data were then coded and summarized by categorizing them into sub- themes. Results of which were made to corroborate with the findings obtained from the quantitative data. 


\section{Results and Discussion}

The demographic characteristics and extent of participation. To fully understand the barangay residents' responses and feelings about the issues considered at hand, data about their demographic characteristics and extent of participation were sought and presented in Table I. As shown, a total of 106 residents participated in the study. Majority of them were of older age (31 years and above), while the rest were 30 years old and below, from which a meager number of young participants $(7.5 \%)$ were observed. This indicates that a considerable number of participants were of older age, consisted mostly of adults, fathers, and mothers, and had families of their own.

Additionally, the table also reveals that the overall extent of participation in the extension activities conducted to the barangay residents was moderate $(M=1.40)$. Interestingly, the younger age group with an age range of 20 years and below indicated the highest mean rating $(M=1.71)$. Likewise, two age groups showed high ratings of participation (21 - 30 years old and $41-50$ years old), showing weighted mean scores of 1.53 and 1.52 respectively. As to sex, the females showed a higher extent of participation $(\mathrm{M}=1.51)$ than the male group $(\mathrm{M}=1.16)$ and as to educational attainment, both the elementary and the high school levels had a moderate participation $(M=1.45$ and $M=1.44$, respectively). Surprisingly, the college level indicated a great extent of involvement $(M=1.67)$ whereas the college degree holders had only a slight participation. This, however was expected because typically, college degree holders prefer to find jobs that are inline with their obtained field. Thus, very few of them were available during the conduct of extension activities. As pointed out by the study participants, many college graduates had already moved out to the cities of Cebu, Manila, and other nearby cities. As to monthly income, high participation was observed among those having low income (less than P3,000.00) which was expected because families with higher income did not bother anymore to participate in the extension activities.

\section{TABLE I}

DEMOGRAPHIC CHARACTERISTICS AND EXTENT OF PARTICIPATION OF THE BARANGAY RESIDENTS

\begin{tabular}{|c|c|c|c|c|c|}
\hline \multicolumn{3}{|l|}{ Socio-demographic } & \multicolumn{3}{|c|}{ Extent of Participation } \\
\hline Characteristics $(\mathrm{n}=106)$ & None & Partial & Full & Mean & Interpretation \\
\hline \multicolumn{6}{|l|}{ Age } \\
\hline $20 \&$ below & 1 & 0 & 6 & 1.71 & High \\
\hline $21-30$ & 0 & 7 & 8 & 1.53 & High \\
\hline $31-40$ & 2 & 10 & 14 & 1.46 & Moderate \\
\hline $41-50$ & 2 & 12 & 19 & 1.52 & High \\
\hline $51 \&$ above & 4 & 12 & 9 & 1.20 & Moderate \\
\hline \multicolumn{6}{|l|}{ Sex } \\
\hline $\begin{array}{l}\text { Male } \\
\text { Female }\end{array}$ & $\begin{array}{l}3 \\
6\end{array}$ & $\begin{array}{l}10 \\
31\end{array}$ & $\begin{array}{c}6 \\
50\end{array}$ & $\begin{array}{l}1.16 \\
1.51\end{array}$ & $\begin{array}{l}\text { Moderate } \\
\text { High }\end{array}$ \\
\hline \multicolumn{6}{|l|}{ Educational Attainment } \\
\hline Elementary & 4 & 21 & 28 & 1.45 & Moderate \\
\hline High School & 4 & 19 & 25 & 1.44 & Moderate \\
\hline College Level & 0 & 1 & 2 & 1.67 & High \\
\hline College Graduate & 1 & 0 & 1 & 1.00 & Slight \\
\hline \multicolumn{6}{|l|}{ Monthly Income } \\
\hline Lower than P3,000.00 & 4 & 33 & 45 & 1.50 & High \\
\hline P $3,000.00-5,999.00$ & 5 & 8 & 11 & 1.25 & Moderate \\
\hline P $6,000.00 \&$ above & - & - & - & - & - \\
\hline Total & $9(8 \%)$ & $41(38 \%)$ & $56(52 \%)$ & 1.38 & Moderate \\
\hline
\end{tabular}

On Barangay Residents' Assessment on the PIT Community Extension Programs. Table II shows the overall assessment/evaluation of the village residents on the extension activities of PIT. As revealed, the training content, categorized into skills training and livelihood program was excellent and very useful, respectively. The methodology and the training facilities/materials were good and effective, the trainers were skillful, and 
the time management was good and enough. Overall, the beneficiaries of the PIT extension programs/ projects/ activities perceived them as good and responsive to the needs of the community.

On Perceived Effect of the PIT Community Extension Services. One way of determining whether an activity has positively 'touched' the lives of the people is to assess its perceived outcome in the community. In the present study, the perceived effect of the PIT community extension programs/projects/activities on the community and on the individual residents was examined. The summary of results is shown in Tables III and IV.

TABLE II

BARANGAY RESIDENTS' ASSESSMENT ON THE PIT COMMUNITY EXTENSION SERVICES

\begin{tabular}{|c|c|c|c|c|c|c|c|}
\hline \multirow[b]{2}{*}{ Criteria } & \multicolumn{5}{|c|}{ No. of respondents (n) } & \multirow[t]{2}{*}{ Mean } & \multirow[t]{2}{*}{ Interpretation } \\
\hline & 5 & 4 & 3 & 2 & 1 & & \\
\hline \multicolumn{8}{|l|}{ Training Content } \\
\hline - Skills Training & 54 & 39 & 12 & 1 & & 4.38 & Excellent \\
\hline - Livelihood Program & 47 & 27 & 24 & 8 & & 4.07 & Very useful \\
\hline Methodology & 37 & 46 & 21 & 1 & 1 & 4.10 & Very effective \\
\hline Expertise of Trainers & 29 & 44 & 28 & 5 & & 3.92 & Skillful \\
\hline Facilities/Materials & 33 & 43 & 24 & 6 & & 3.97 & Very good \\
\hline Time Management & 14 & 48 & 39 & 5 & & 3.67 & Good/enough time \\
\hline Responsiveness & 21 & 37 & 28 & 20 & & 3.56 & Responsive \\
\hline Overall Perception & & & & & & 3.95 & Very good \\
\hline
\end{tabular}

Table III reveals that the overall perceived effect of the PIT extension activities on the individual residents was good $(\mathrm{M}=3.98)$. The residents strongly agreed that they had gained knowledge and skills from the skills training attended. Remarkably, the respondents were undecided whether or not the extension activities which they participated in had helped them in augmenting their income. This result needs further validation, hence, scheduled interviews and FGDs were deemed necessary.

TABLE III

PERCEIVED EFFECT OF PIT EXTENSION PROGRAMS/ ACTIVITIES ON THE RESIDENTS

\begin{tabular}{|c|c|c|c|c|c|c|c|c|}
\hline & \multicolumn{5}{|c|}{ No. of Respondents } & & \multirow[b]{2}{*}{ Mean } & \multirow[b]{2}{*}{ Interpretation } \\
\hline $\begin{array}{l}\text { Perceived effect on the individual } \\
\text { residents }\end{array}$ & 5 & 4 & 3 & 2 & 1 & $\mathrm{n}$ & & \\
\hline 1. It helped boost my confidence. & 40 & 23 & 10 & 3 & 4 & 80 & 4.15 & Agree \\
\hline 2. It helped me find a job. & 36 & 22 & 16 & 12 & 4 & 90 & 3.82 & Agree \\
\hline 3. I gained knowledge and skills. & 52 & 25 & 8 & 3 & 5 & 93 & 4.25 & Strongly Agree \\
\hline $\begin{array}{l}\text { 4. It provided useful information } \\
\text { about causes and consequences. }\end{array}$ & 40 & 25 & 10 & 5 & 2 & 82 & 4.17 & Agree \\
\hline 5. It helped me augment my income. & 27 & 17 & 20 & 20 & 9 & 93 & 3.35 & Undecided \\
\hline $\begin{array}{l}\text { 6. Scolding of children by parents } \\
\text { was minimized. (for the youth). }\end{array}$ & 36 & 25 & 16 & 3 & 1 & 81 & 4.14 & Agree \\
\hline \multicolumn{9}{|c|}{ Overall Effect on the Individual Residents } \\
\hline
\end{tabular}

4.20 - 5.00 - Very Good; 3.40 - 4.19 - Good; 2.60 - 3.39 - Slightly Good;

1.8 - 2.59-Needs Improvement; 1.00-1.79-Not Good at all 
As to the effect of the PIT extension programs on the community, findings showed a good overall effect (Mean $=3.98)$. The villagers believed that the activities had provided them the chance to acquire necessary skills that would somehow help them improve their living conditions. In some way, they also agreed that their children's participation in the various extension activities had prevented them to indulge to some vices such as gambling and drugs. However, they were undecided as to whether or not these extension activities had helped them in augmenting their income, had improved their living conditions or had caused poverty alleviations. In fact, they openly said that they learned skills from the training but had neither benefited from nor earned extra income due to lack of capital and opportunities. This result is also supported by the early findings of this study revealing that after extending community services to Barangay Canipaan, the people's income remains in the marginal level (P3,000.00 and below).

\section{TABLE IV \\ PERCEIVED EFFECT OF PIT EXTENSION PROGRAMS/ ACTIVITIES ON THE COMMUNITY}

\begin{tabular}{|c|c|c|c|c|c|c|c|c|}
\hline \multirow[t]{2}{*}{ Perceived Effect on the Community } & \multicolumn{6}{|c|}{ No. of Respondents } & \multirow[t]{2}{*}{ Mean } & \multirow{2}{*}{$\begin{array}{l}\text { Degree of } \\
\text { Agreement }\end{array}$} \\
\hline & 5 & 4 & 3 & 2 & 1 & $\mathrm{n}$ & & \\
\hline 1. It helped a lot to the community. & 54 & 23 & 8 & 6 & 2 & 93 & 4.30 & Strongly Agree \\
\hline 2. It enhanced the skills of the residents, & 48 & 33 & 8 & 4 & & 93 & 4.34 & Strongly Agree \\
\hline 3. It helped in promoting cleanliness. & 41 & 25 & 18 & 5 & 1 & 90 & 4.11 & Agree \\
\hline 4. It helped augment income of the families. & 18 & 23 & 15 & 26 & 11 & 93 & 3.12 & Undecided \\
\hline 5. It improved the living conditions of the & \multirow[t]{2}{*}{19} & \multirow[t]{2}{*}{21} & \multirow[t]{2}{*}{31} & \multirow[t]{2}{*}{12} & \multirow[t]{2}{*}{9} & \multirow[t]{2}{*}{92} & \multirow[t]{2}{*}{3.31} & \multirow[t]{2}{*}{ Undecided } \\
\hline people in the community & & & & & & & & \\
\hline 6. It reduced poverty. & 20 & 15 & 26 & 25 & 7 & 93 & 3.17 & Undecided \\
\hline $\begin{array}{l}\text { 7. It prevented the youth and other barangay } \\
\text { residents not to indulge to vices. }\end{array}$ & 37 & 30 & 9 & 9 & 7 & 92 & 3.88 & Agree \\
\hline
\end{tabular}

On Field Observation and Dialogue with the Barangay Residents. One way of validating questionnaire responses is to conduct physical visit and interviews. This is also a way of collecting first-hand information about the community program/activity impacts. Thus, the researchers scheduled field observations and dialogues with the barangay residents whom they asked about how they felt about the various extension activities conducted, including the social services extended to the community such as the rehabilitation of their social center and chapel, and the installation of water facilities and solar panel in the community. The researchers also wanted to personally see and ask the people's living conditions, asking them whether or not the community extension activities and projects had improved their lives and/or had indicated positive impacts on them.

The researchers tried to encourage interviewees to be truthful in their answers, telling them that the interviews were only valuable if they shared their real experiences with PIT. One technique done was to emphasize that the results of this study would change and improve future practices so that PIT could be of better service to them. The activity was guided by a series of pre-determined questions, but the interviews were kept flexible to gather the maximum amount of information possible.

As such, during the actual interview, the researchers felt that talking to the residents of the community partner and listening to them were very inspiring. The residents shared their stories, and personal feelings about the activities which they participated in, including their insights on the learned skills which according to them were helpful and useful, had they have the capital needed and work opportunities to avail of.

During the interview, the villagers were generous with their time and with the level of details given to describing the outcomes of the extension projects and activities. The stories were even felt more encouraging 
because the residents unanimously revealed that the concrete projects provided were found very beneficial and significant to them. These included the benefits they enjoyed from the projects. Majority of them said:

We have learned a lot of skills from the various trainings conducted in the community. However, as of now, these have not helped us augment our earnings/income. This is because we do not have the capital and opportunities. We are financially incapable.

Another group of the Sitio Mahayahay residents pointed out and said "We are very thankful for the trainings conducted in our barangay. We have learned a lot from those trainings". Moreover, three residents agreed to say that:

We are very happy that we already have the knowledge in basic dressmaking. Yes, we can already sew some household items such as pillowcases, curtains, skirts, simple blouses, etc. With this, we are very thankful to the school. However, for now, we have not learned anything from it. We see no opportunity to make use of it because we do not have the initial capital to start with.

On the other hand, in the interviews conducted at Sitio Mahayahay, a couple of the residents openly said that:

We are genuinely thankful to the school for giving us the water pump facilities. This is very helpful to us. The water pump, for example, lightens our work. It improves our living conditions. Water is no longer a problem in the community. Unlike before, our water source was very far. Now, doing house chores is easier; our children, especially those who are studying can already take a bath daily. We really thank PIT forthis.

Furthermore, one common remarkable statement of the sitio residents runs as follows:

"Because of the solar panel, the streets of our community are already well-lighted. The residents are no longer afraid of going out and walking along the streets is already safe. We are very thankful to PIT and its Dutch partner - the KVNR for providing us the facilities".

On the whole, the Sitio Mahayahay folks graciously opened that the restoration of their social center and chapel, and the installation of the water facilities and solar panel had given significant impact to them and to the whole community. The researchers observed the enthusiasm of the residents when they mentioned about the contribution of the projects. It was very visible on their faces as they sincerely expressed their gratitude to PIT and the College of Maritime Education in particular. Almost all Sitio Mahayahay residents agreed that the projects installed in their community have significantly improved their way of living.

On the other hand, the Mat-i, Crossing and the barangay proper residents revealed similar sentiments with the Sitio Mahayahay residents. They expressed similar viewpoints with regards to the skills learned from the extension activities conducted in their respective area. Majority of them openly shared that much as they wanted to utilize their learned skills however, they could not because they do not have the necessary capital, no opportunities, and no equipment/facilities and materials for them to start with.

\section{CONCLUSION}

The preceding qualitative findings affirm with the quantitative findings presented earlier. PIT's community extension programs and projects brought to Barangay Canipaan - specifically to its four sitios (Mahayahay,Mat- I, Crossing and Barangay Canipaan proper) were successfully conducted and effectively delivered by the school's trainers. However, the residents may have participated actively in the activities and have learned skills, yet these have not helped them augment their income and therefore have not helped them in uplifting their lives. While it is true that these residents were provided with some useful concrete projects that made their community a better place to live in, however, such is more of a social responsibility. PIT should also consider that the success of community extension services is measured not only what people say about it but also how the positive impacts of the programs, projects and activities are brought to the community, whether these improve the lives of the people by increasing their incomes and thereby, reduce poverty [1].

\section{RECOMMENDATIONS}

Based on the findings and conclusions drawn from the study, it is strongly recommended that the Institute through the Office of Extension Services has to:

1. Discuss strategic ways and effective strategies to improve the community extension services. 
2. Strengthen initiatives such as linkages and partnership with other agencies that can help and provide the people with the necessary capital and work/employment opportunities.

3. Undertake re-planning of its community extension activities on the basis of the residents' needs and feedback to address community problems and issues.

4. Conduct proper and regular monitoring and evaluation for every extension project/activity undertaken in order to identify strengths and weaknesses including relevance and sustainability.

5. Establish linkages with the local and national government agencies like Department of Trade and Industry (DTI) and non-government agencies, and cooperatives for funding as sources of microfinancing programs for individuals, small-scale and medium enterprise establishments.

\section{REFERENCES}

[1] Alcala, Angel (2016). Research, Extension Programs in HEIs. Metro Post http://dumaguetemetropost.com/research-extension-programs-in-heis-p698298.htm

[2] Bidad, Clarita D. and Campiseño, Evelyn R. (2010).Community Extension Services of SUCsin Region IX,: Basis for Sustainable Community Enhancement Program. E-International Scientific Research Journal. ISSN: 2094-1749 Volume: 2 Issue: 3 , 2010. Retrieved from http://www.eisrjc.com/documents/Community_Ex tension_Services_Of_SUCs_1325929936.pdf

[3] CMO No. 08, s. 2010. Revised Guidelines forthe Higher Education Institution (HEI) Extension Program Award. Retrieved from http://www.ched.gov.ph/wp- content/uploads/2013/07/CMO-No.08-s2010.pdf on April 25,2016.

[4] Dilao, Anilou Bayron (n.d.). Impact of Community Extension Program on the Residents of Barangay Catadman-Manabay. Retrieved from http://local.lsu.edu.ph/institutional_research_offic e/publications/vol.15no.6/6.html

[5] Palompon DSWD Record File, 2013). Department of Social Welfare and Development, Municipality of Palompon, Palompon, Leyte.

[6] Dugyo, Eva Marie Codamon (2016). Impact of Community Extension Programs on the Residents of Selected Adopted Barangays of Ifugao State University, Philippines. Retrieved from: https//www.scribd.com/document/319075221//MPACT-OF-COMMUNITY-EXTENSION-PROGRAMS-ON-THE-RESIDENTS-OF-SELECTEDADOPTED-BARANGAYS-OFIFUGAO-STATE-UNIVERSITY-PHILIPPINES.

[7] EARIEST Extension Manual 2015 (2013).http://earist.edu.ph/_assets/2015/EARIST\%20EXTENSION\%20MANUAL\%202015.pdf

[8] Herrera, Fernando T. (2009). "Impact Assessment of Community Extension Servicesof Saint Joseph Institute of Technology". Vol. 4. January 2010. Retrievedfrom http://ejournals.ph/index.php?journal=JPAIRMJ\&page=article\&op=view \&path[]=3751\&path[]=3972

[9] Malipot, Ina (Apr 07 2011). MSUIIT News. “CHEd cites 14 higher education institutions" Retrieved from https://www.msuiit.edu.ph/news/news-detail.php?id=239

[10] MOJARES, Juvy Geneta; BACONGUIS, Rowena DT. Extension Function in Higher Educational Institutions: Learning from HEIs in Batangas Province, Philippines. USM R\&D Journal, [S.1.], jun. 2015. ISSN2362-9231.Retrieved from <http://www.usm.edu.ph/onlinejournal/index.php/USMJournal/article/view/115>.

[11] PIT-Extension Services Office Annual Reports (2013-2014)

[12] PIT Extension Services Manual of Operation, 2012

[13] RA No. 7722 otherwise known as“Higher Education Act of1994”.

[14] Republic Act 8292 otherwise known as the "Higher Education Modernization Act of1997" 